\title{
Safety and effectiveness of the high-frequency chest wall oscillation vs intrapulmonary percussive ventilation in patients with severe COPD
}

This article was published in the following Dove Press journal:

International Journal of COPD

\author{
Antonello Nicolini' \\ Bruna Grecchi ${ }^{2}$ \\ Maura Ferrari-Bravo ${ }^{3}$ \\ Cornelius Barlascini ${ }^{4}$ \\ 'Respiratory Diseases Unit, Hospital \\ of Sestri Levante, Sestri Levante, Italy; \\ ${ }^{2}$ Rehabilitation Unit, ASL4 Chiavarese, \\ Chiavari, Italy; ${ }^{3}$ Statistics Unit, ASL4 \\ Chiavarese, Chiavari, Italy; ${ }^{4}$ Health \\ Medicine Unit, Hospital of Sestri \\ Levante, Sestri Levante, Italy
}

\begin{abstract}
Purpose: Chest physiotherapy is an important tool in the treatment of COPD. Intrapulmonary percussive ventilation (IPV) and high-frequency chest wall oscillation (HFCWO) are techniques designed to create a global percussion of the lung which removes secretions and probably clears the peripheral bronchial tree. We tested the hypothesis that adding IPV or HFCWO to the best pharmacological therapy (PT) may provide additional clinical benefit over chest physiotherapy in patients with severe COPD.
\end{abstract}

Methods: Sixty patients were randomized into three groups (20 patients in each group): IPV group (treated with PT and IPV), PT group with (treated with PT and HFCWO), and control group (treated with PT alone). Primary outcome measures included results on the dyspnea scale (modified Medical Research Council) and Breathlessness, Cough, and Sputum scale (BCSS), as well as an evaluation of daily life activity (COPD Assessment Test [CAT]). Secondary outcome measures were pulmonary function testing, arterial blood gas analysis, and hematological examinations. Moreover, sputum cell counts were performed at the beginning and at the end of the study.

Results: Patients in both the IPV group and the HFCWO group showed a significant improvement in the tests of dyspnea and daily life activity evaluations (modified Medical Research Council scale, BCSS, and CAT) compared to the control group, as well as in pulmonary function tests (forced vital capacity, forced expiratory volume in 1 second, forced expiratory volume in 1 second/forced vital capacity $\%$, total lung capacity, residual volume, diffusing lung capacity monoxide, maximal inspiratory pressure, maximal expiratory pressure) and arterial blood gas values. However, in the group comparison analysis for the same variables between IPV group and HFCWO group, we observed a significant improvement in the IPV group maximal inspiratory pressure, maximal expiratory pressure, BCSS, and CAT. Similar results were observed in changes of sputum cytology with reduction of inflammatory cells (neutrophils and macrophages).

Conclusion: The two techniques improved daily life activities and lung function in patients with severe COPD. IPV demonstrated a significantly greater effectiveness in improving some pulmonary function tests linked to the small bronchial airways obstruction and respiratory muscle strength and scores on health status assessment scales (BCSS and CAT) as well as a reduction of sputum inflammatory cells compared with HFCWO.

Keywords: severe COPD, intrapulmonary percussive ventilation, high-frequency chest wall oscillation, daily life activity

\section{Introduction}

COPD is a lung disease characterized by chronic airflow limitation associated with an enhanced chronic inflammatory response to noxious particles or gases. ${ }^{1}$ Mucus
Correspondence: Antonello Nicolin Hospital, Via Terzi 43 - 16039,

Sestri Levante, Italy

Tel +39018 5329145

$\mathrm{Fax}+390185329935$

Email antonellonicolini@gmail.com (c) (1) (5) 2018 Nicolini et al. This work is published and licensed by Dove Medical Press Limited. The full terms of this license are available at https://www.dovepress.com/terms.php cc) hereby accept the Terms. Non-commercial uses of the work are permitted without any further permission from Dove Medical Press Limited, provided the work is properly attributed. For permission for commercial use of this work, please see paragraphs 4.2 and 5 of our Terms (https://www.dovepress.com/terms.php). 
hypersecretion in COPD has many common causes; some of these include cigarette smoke, acute and chronic viral infection, bacterial infection, and/or inflammatory cell activation of mucin gene transcription. ${ }^{2}$ The overproduction of mucus and the hypersecretion from increased degranulation is mediated by neutrophil elastase. ${ }^{3}$ Moreover, there is a difficulty in clearing secretions because of poor ciliary function, distal airway occlusion, and/or an ineffective cough along with reduced peak expiratory flow. This leads to progressive decline in lung function. ${ }^{1,4}$ Respiratory chest physiotherapy and assisted mucus-clearing techniques are critically important in COPD patients. ${ }^{5}$ Postural drainage, assisted cough, active cycle of breathing techniques, autogenic drainage, forced expiratory technique, positive expiratory pressure devices, ${ }^{6}$ oscillatory positive-expiratory pressure devices ${ }^{7}$ and, more recently, high-frequency chest wall oscillation (HFCWO), ${ }^{8}$ intermittent positive pressure breathing (IPPB), ${ }^{9}$ intrapulmonary percussive ventilation (IPV), ${ }^{10}$ and temporary positive expiratory pressure ${ }^{11,12}$ are the techniques that have been proposed over the years for secretion management. The efficacy of these techniques during acute exacerbation or stable disease remains unclear. ${ }^{13}$ Osadnik et $\mathrm{al}^{13}$ reviewed twenty-eight studies including 907 participants in a metaanalysis; however, the quality was considered poor due to inadequate blinding and allocation procedure and the results were limited by heterogeneity of outcome measurement and inadequacy of data. The conclusions were that airway clearance techniques are safe for individuals with COPD, but the benefits are less clear. IPV was designed to promote mobilization of bronchial secretions and improve efficiency and distribution of ventilation, providing intrathoracic percussion and vibration and an alternative system for the delivery of the positive pressure to the lungs. HFCWO involves an inflatable jacket that is attached to a pulse generator by hoses that mechanically enable the equipment to perform at variable frequencies $(5-25 \mathrm{~Hz}) .{ }^{14}$ The generator sends air through the hose, which causes the vest to inflate and deflate rapidly. The vibrations not only separate mucus from the airway walls but also help move it up into the large airways. ${ }^{15}$ Regarding these two different techniques, we conducted a randomized controlled study aimed at comparing their short-term effects in severe to very severe (Global Initiative for Chronic Obstructive Lung Disease [GOLD] stage 3-4, assessment C-D) COPD patients.

\section{Methods}

The study was carried out at the Pulmonary Rehabilitation Center of the Respiratory Diseases Department of General Hospital of Sestri Levante from April 2013 to December
2013 and was approved by Local Ethics Committee. Written informed consent was obtained from all participants and procedures were conducted according to the Declaration of Helsinki. The study was registered with the Chinese Clinical Trial Registry, with the number ChiCTR-TRC12002133.

\section{Patients}

Seventy nine patients with stable severe to very severe COPD admitted to The Rehabilitation outpatient clinic were recruited. Inclusion criteria were as follows: age at least 35 years, presence of chronic bronchitis and airway obstruction on spirometry (GOLD stage 3-4, C-D assessment), bronchial hypersecretion (daily sputum $>20 \mathrm{~mL}$ for at least 2 consecutive days), and effective cough (peak expiratory cough flow $>360 \mathrm{~L} / \mathrm{min}$ ). Exclusion criteria were the following: exacerbation of COPD or hospitalization for COPD within 8 weeks prior to recruitment, history of bronchial asthma, predominant bronchiectasis, presence of tracheostomy, mechanical ventilation, recent pneumothorax, severe abnormalities of sensory, severe cardiac arrhythmias, hemodynamic instability, and chest radiograph changes. The drop-out criteria were the inability to comply to study procedures or the lack of a written informed consent and the occurrence of any of the exclusion criteria.

\section{Protocol}

This was a 4-week parallel randomized controlled study comparing IPV, HFCWO, and the best medical therapy. The aim of the study was to verify the effectiveness and the patients' preference regarding the two methods. Patients who met inclusion criteria were enrolled and randomized into three groups as depicted in the flowchart in Figure 1. A randomization schedule was generated by an independent statistician using an online random permutation generator from $\underline{\mathrm{http}: / /}$ www.randomization.com. The randomization assignments were provided to the physicians in sealed envelopes. The investigators who carried out the study data analysis were blinded to patients' treatment assignment.

\section{Treatments protocols}

IPV was provided by a respiratory physiotherapist using a percussive ventilator (IPV Impulsator, Percussionaire) (Figure 2A). The impact of calibration (adjustment of inspiratory to expiratory ratio), percussion (frequency of delivered breaths), and source pressure (amplitude/pressure rise of delivered breaths) was adjusted using some suggested setting parameters. ${ }^{10}$ Each IPV session lasted fifteen minutes 


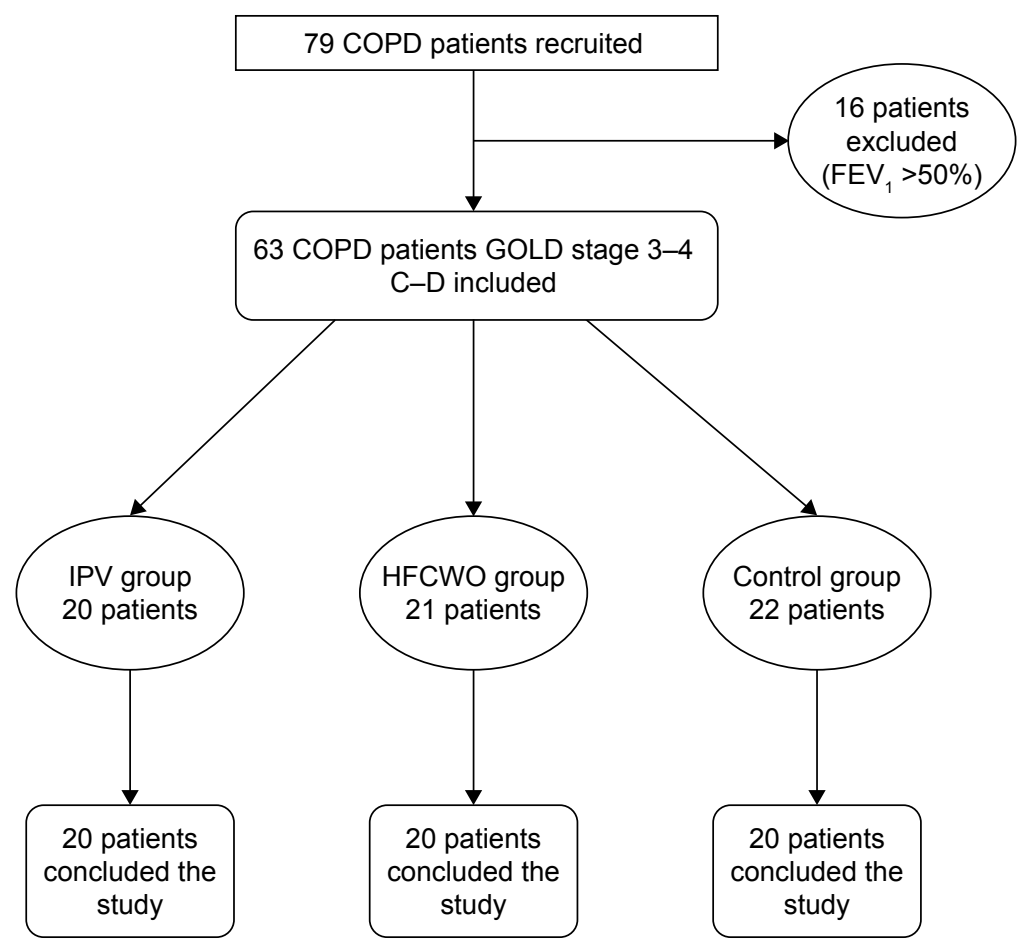

Figure I Flow chart detailing study methodology.

Abbreviations: GOLD, Global Initiative for Chronic Obstructive Lung Diseases; FEV , forced expiratory volume I second; HFCWO, high-frequency chest wall oscillation; IPV, intrapulmonary percussive ventilation.

and was performed twice a day (morning and afternoon). HFCWO was delivered by a respiratory physiotherapist using a percussive vest (The Vest Airway Clearance System Model 205, Hill-Rom, Batesville, IN, USA) (Figure 2B) at 13-15 Hz oscillating frequency, based on patient's tolerance, and at a pressure setting of $2-5 \mathrm{~cm} \mathrm{H}_{2} \mathrm{O}$ to achieve a tight but comfortable snug fit. ${ }^{14,15}$ Each HFCWO session lasted 20 minutes and was performed twice a day (morning and afternoon). Subjects for both procedures were kept in a sitting position. The duration of the treatments for each group was 2 weeks. The patients were evaluated one week before the start of airway clearance treatment and one week after the end of the treatment.

\section{Measurements and outcomes}

The primary outcomes of the study were the assessment of changes in dyspnea and quality of life as well as daily life activity and healthy status assessment. The secondary outcomes were changes in respiratory function testing, hematological tests, and sputum cell count.
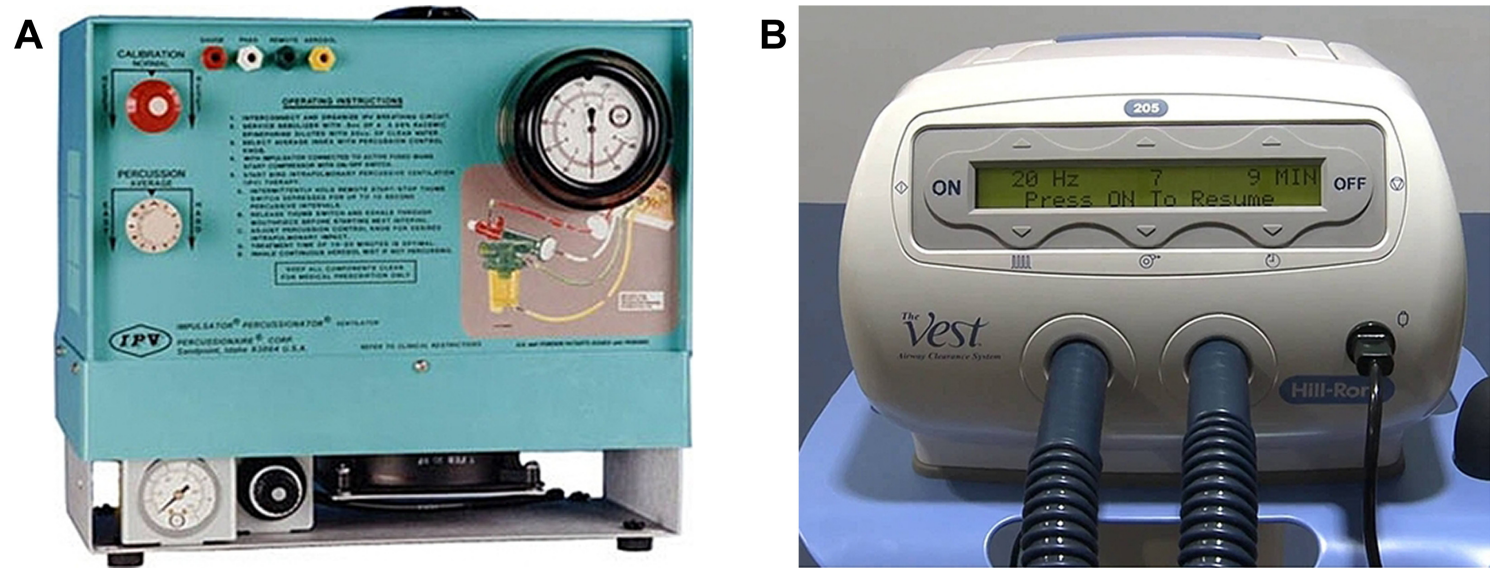

Figure 2 (A) Intrapulmonary percussive ventilator. (B) High-frequency chest wall oscillator. 
Dyspnea was measured with the Modified Medical Research Council (mMRC) Dyspnea Scale; ${ }^{16}$ cough and sputum was assessed with the Breathlessness, Cough, and Sputum Scale (BCSS); ${ }^{17,18}$ daily life activity and healthy status assessment were measured with COPD Assessment Test (CAT). ${ }^{19,20}$ Pulmonary function testing including forced vital capacity (FVC), forced expiratory volume 1 second $\left(\mathrm{FEV}_{1}\right), \mathrm{FEV}_{1} / \mathrm{FVC} \%$, total lung capacity (TLC), residual volume (RV), diffusing lung capacity monoxide (DLCO), maximal inspiratory pressure (MIP), maximal expiratory pressure (MEP), peak cough expiratory flow, and arterial blood gas analysis $\left(\mathrm{Pao}_{2}, \mathrm{Paco}_{2}, \mathrm{pH}\right)$ were performed with a computerized body plethysmography (VMAX 20 PFT Sensor Medics, Yorba Linda, CA, USA), according to the ATS/ERS Guidelines. ${ }^{21-23}$ Inspiratory muscle strength was assessed by measuring the MIP at RV. Expiratory muscle strength was assessed by measuring the MEP at TLC. The value obtained from the best of at least three effort was used. All the measurements were obtained in an upright position..$^{24,25}$ Diagnosis and severity of COPD were confirmed using the GOLD Guidelines. ${ }^{26}$

Sputum collection was made on the day the treatment was started and on the day of the last treatment. The patients were instructed by the physiotherapists or by the nurses to expectorate into the sputum cups during the entire duration of the treatment and to continue expectorating if the patient felt the need to cough. Sputum induction was performed using a previously described method. Briefly, the procedure was started 10 minutes after the administration of $200 \mu \mathrm{g}$ of inhaled salbutamol using a 3\% hypertonic saline solution. Sputum samples were processed within 2 hours after the collection. ${ }^{27-29}$ Sputum samples were considered for analysis if they contained expectorated material with cellular viability greater than $50 \%$, had contamination with oropharyngeal squamous cells at a level lower than $20 \%$, and were of sufficient quantity to enable differential counts of 400 cells..$^{28,29}$ Finally at the end of treatment, subjects treated with IPV or HFCWO were asked to complete a written questionnaire to rate comfort, effectiveness, ease of use, and convenience of the respective procedures. The answers were given using a 5-point Likert-type scale. The possible responses were extremely $=4$, very $=3$, somewhat $=2$, not very $=1$, not at all $=0 .{ }^{30}$

\section{Statistical analysis}

Clinical data were expressed as counts and mean and SD. We calculated the difference between the two treatments (HFCWO and IPV) and control group using univariate regression analysis. Subsequently, the difference between the two treatments (HFCWO and IPV) was analyzed using univariate regression analysis. In addition, a Wilcoxon test was applied to the patients' preference rankings. Differences were considered statistically significant when $p \leq 0.05$. Data analysis was performed using the statistics software R-Project version 2.13.2.

\section{Results}

Sixty-three patients were recruited. Three patients withdrew prior to completing the study. Two patients belonged to the control group and one patient belonged to HFCWO group. Sixty patients completed the study. All patients had similar characteristics. The patient characteristics are given in Table 1 . No changes in respiratory therapy or COPD exacerbations were observed during the study period.

Table I Demographic, clinical, and functional parameters at baseline in the three groups

\begin{tabular}{|c|c|c|c|c|}
\hline Variable & $\begin{array}{l}\text { Control } \\
\text { group } \\
(n=22)\end{array}$ & $\begin{array}{l}\text { IPV } \\
\text { group } \\
(n=20)\end{array}$ & $\begin{array}{l}\text { HFCWO } \\
\text { group } \\
(n=2 I)\end{array}$ & $p$-value \\
\hline \multicolumn{5}{|c|}{ Demographic and clinical characteristics } \\
\hline Age (years) & $74.9 \pm 2.7$ & $72.8 \pm 6.1$ & $73.8 \pm 5.9$ & 0.22 \\
\hline Male (\%) & II (50.0) & I5 (75.0) & $9(42.8)$ & 0.07 \\
\hline BMI $\left(\mathrm{kg} / \mathrm{m}^{2}\right)$ & $25.9 \pm 3.7$ & $25.8 \pm 4.3$ & $24.9 \pm 5.8$ & 0.11 \\
\hline $\begin{array}{l}\text { Exacerbations } \\
\text { per year (n) }\end{array}$ & $2.3 \pm 0.3$ & $2.4 \pm 0.2$ & $2.5 \pm 0.3$ & 0.12 \\
\hline $\begin{array}{l}\text { Hospitalizations } \\
\text { per year }(n)\end{array}$ & $1.1 \pm 0.3$ & $1.3 \pm 0.4$ & $1.2 \pm 0.3$ & 0.14 \\
\hline \multicolumn{5}{|c|}{ Clinical and functional parameters } \\
\hline $\mathrm{PaO}_{2}$ & $69.8 \pm 10.4$ & $71.8 \pm 7.8$ & $72.0 \pm 10.0$ & 0.18 \\
\hline $\mathrm{PaCO}_{2}$ & $41.7 \pm 6.0$ & $42.5 \pm 4.8$ & $41.8 \pm 2.7$ & 0.21 \\
\hline $\mathrm{pH}$ & $7.4 \pm 0$ & $7.4 \pm 0$ & $7.4 \pm 0$ & 0.19 \\
\hline $\mathrm{HCO}_{3}$ & $24.6 \pm 1.5$ & $23.3 \pm 2.0$ & $24.8 \pm 1.9$ & 0.20 \\
\hline FVC\% & $61.1(16.3)$ & $58.7(13.4)$ & $56.4(13.2)$ & 0.15 \\
\hline $\mathrm{FEV}_{1} \%$ & $36.2 \pm 2.7$ & $36.7 \pm 1.8$ & $38.9 \pm 2.7$ & 0.07 \\
\hline $\mathrm{FEV}_{1} / \mathrm{FVC} \%$ & $46.1 \pm 12.7$ & $48.8 \pm 13.7$ & $56.9 \pm 10.7$ & 0.10 \\
\hline TLC\% & $140.6 \pm 22.2$ & $117.3 \pm 31.7$ & $132.5 \pm 34.7$ & 0.11 \\
\hline RV\% & $192.4 \pm 67.0$ & $183.0 \pm 66.8$ & $149.6 \pm 39.3$ & 0.09 \\
\hline DLCO\% & $52.9 \pm 5.6$ & $60.6 \pm 15.0$ & $65.8 \pm 12.1$ & 0.06 \\
\hline MIP & $5.7 \pm 2.0$ & $6.2 \pm 2.0$ & $6.6 \pm 3.1$ & 0.09 \\
\hline MEP & $6.5 \pm 2.7$ & $7.4 \pm 1.9$ & $7.1 \pm 1.9$ & 0.08 \\
\hline 6MWT (mt) & $240 \pm 30$ & $242 \pm 26$ & $265 \pm 55$ & 0.10 \\
\hline CRP & $0.5 \pm 0.4$ & $1.0 \pm 0.7$ & $1.5 \pm 1.6$ & 0.06 \\
\hline rGL & $12.7 \pm 3.9$ & $15.0 \pm 2.0$ & $16.8 \pm 5.3$ & 0.06 \\
\hline \multicolumn{5}{|l|}{ Scales } \\
\hline mMRC scale & $3.2 \pm 0.9$ & $2.7 \pm 0.9$ & $2.5 \pm I . I$ & 0.07 \\
\hline CAT score & $23.2 \pm 8.1$ & $24.1 \pm 5.9$ & $24.6 \pm 5.8$ & 0.10 \\
\hline BCSS & $4.9 \pm 1.4$ & $6.3 \pm 1.4$ & $6.4 \pm 2.6$ & 0.06 \\
\hline
\end{tabular}

Notes: Data are expressed as mean $\pm S D$, unless otherwise stated. $p$-value $<0.05$; F-test for continuous variables and $\chi^{2}$ for categorical variables.

Abbreviations: 6MWT, 6-minute walk test; rGL, gammaglobulin; BCSS, Breathlessness, Cough and Sputum Scale; BMI, body mass index; CAT, COPD Assessment Test; CRP, C-reactive protein; DLCO, diffusing lung capacity monoxide; $\mathrm{FEV}_{1}$, forced expiratory volume in I second; FVC, forced vital capacity; HFCWO, high-frequency chest wall oscillation; IPV, intrapulmonary percussive ventilation; MEP, maximal expiratory pressure; MIP, maximal inspiratory pressure; mMRC, modified Medical Research Council; RV, residual volume; TLC, total lung capacity. 
Table 2 Results of primary outcomes

\begin{tabular}{|c|c|c|c|c|c|c|c|c|c|}
\hline & \multicolumn{3}{|c|}{ Before treatment } & \multicolumn{3}{|c|}{ After treatment } & \multicolumn{3}{|c|}{$\begin{array}{l}\text { Regression analysis } \\
\text { p-value }\end{array}$} \\
\hline & $\begin{array}{l}\text { Control } \\
\text { group }\end{array}$ & $\begin{array}{l}\text { IPV } \\
\text { group }\end{array}$ & $\begin{array}{l}\text { HFCWO } \\
\text { group }\end{array}$ & $\begin{array}{l}\text { Control } \\
\text { group }\end{array}$ & $\begin{array}{l}\text { IPV } \\
\text { group }\end{array}$ & $\begin{array}{l}\text { HFCWO } \\
\text { group }\end{array}$ & $\begin{array}{l}\text { IPV vs } \\
\text { control }\end{array}$ & $\begin{array}{l}\text { HFCWO } \\
\text { vs control }\end{array}$ & $\begin{array}{l}\text { IPV vs } \\
\text { HFCWO }\end{array}$ \\
\hline Sex $=0$ & 10 & 15 & 9 & & & & & & \\
\hline Sex $=1$ & 10 & 5 & 11 & & & & & & \\
\hline Age (years) & $74 \pm 3$ & $72 \pm 7$ & $74 \pm 6$ & & & & & & \\
\hline BCSS & $4.6 \pm 1.7$ & $6.3 \pm 1.4$ & $6.6 \pm 2.8$ & $5.5 \pm 2.1$ & $3.1 \pm 1.7$ & $5.2 \pm 2.2$ & $<0.001$ & 0.007 & $0.001 *$ \\
\hline $\mathrm{mMRC}$ & $3.1 \pm 0.8$ & $2.7 \pm 0.9$ & $2.5 \pm 1.0$ & $3.2 \pm 0.8$ & $2.4 \pm 0.9$ & $2.4 \pm 0.9$ & $0.0 I^{* *}$ & $0.04^{* *}$ & 0.6 \\
\hline CAT & $23.7 \pm 7.4$ & $24.7 \pm 5.9$ & $24.9 \pm 6.4$ & $26.9 \pm 7.6$ & $17.0 \pm 6.3$ & $20.9 \pm 6.9$ & $<0.001$ & $<0.001$ & $0.02 * *$ \\
\hline
\end{tabular}

Note: Data are expressed as mean \pm SD.

Abbreviations: BCSS, Breathlessness, Cough and Sputum Scale; CAT, COPD Assessment Test; HFCWO, high-frequency chest wall oscillation; IPV, intrapulmonary percussive ventilation; mMRC, modified Medical Research Council.

\section{Primary outcomes}

Patients in both the IPV group and the HFCWO group showed a significant improvement in the tests of dyspnea and daily life and health status assessment (mMRC, BCSS, and CAT) compared to those in the control group. Moreover, IPV patients showed an improvement in BCSS $(p<0.001)$ and CAT $(p<0.02)$ scores in comparison with HFCWO. The results are reported in Table 2. The box-plots of BCSS and CAT scores are shown in Figure 3.

\section{Secondary outcomes}

Both the techniques improved several parameters in the patient groups compared to control group (white blood cells, neutrophils, and lymphocytes; C-reactive protein; FVC; $\mathrm{FEV}_{1} ; \mathrm{FEV}_{1} / \mathrm{FVC} \%$; TLC; RV; RV/TLC\%; DLCO; MIP; $\mathrm{MEP} ; \mathrm{PaO}_{2} ; \mathrm{PaCO}_{2}$; and $\left.\mathrm{pH}\right)$. However, in the group comparison analysis for the same variables between IPV group and HFCWO group, we observed a significant improvement in the IPV group in TLC and TLC $\%(p<0.03), \mathrm{RV}$ and $\mathrm{RV} \%$ $(p<0.04)$, and DLCO, MIP, and MEP $(p<0.01)$. These results are summarized in Table 3 .

\section{BCSS}

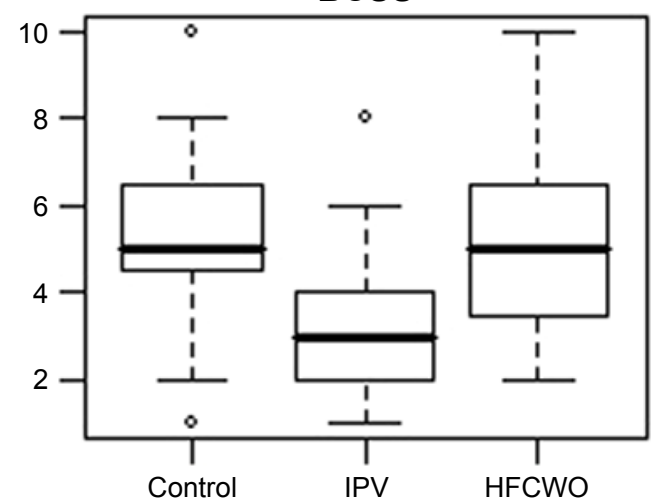

\section{Sputum changes}

A significant change in total cell count and neutrophil, lymphocyte, and macrophage counts in sputum samples were observed in the patients receiving either of the two treatments (IPV and HFCWO) compared to control group. Only a slight significant change in neutrophil count was observed in the IPV group compared to HFCWO group $(p<0.05)$. All the results of the sputum cells count measurements are reported in Table 4.

\section{Measurement of patient acceptability}

The 40 patients who finished the study (20 in each group) completed the questionnaire and rated the comfort, efficacy, ease of use, and convenience. A similar ranking was expressed by the patients for both the techniques. Table 5 shows the mean \pm SD rating and the ranking.

\section{Discussion}

Techniques for increasing the normal airway clearance are a vital component of therapy. Mechanisms which can be performed without an assistant or without being dependent on a

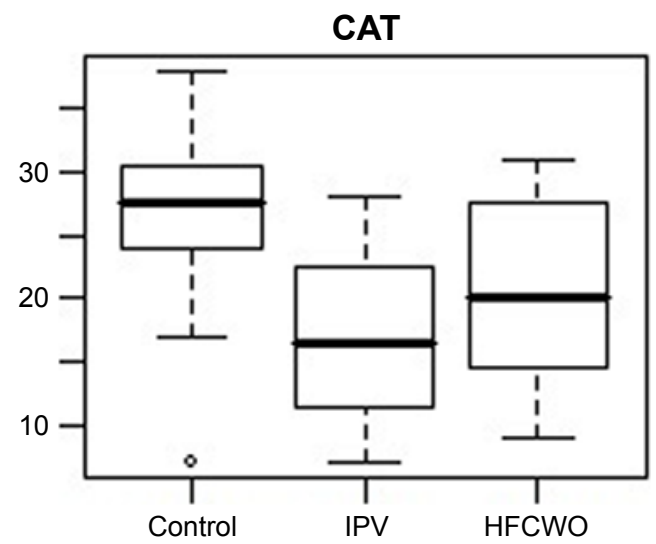

Figure 3 Median changes in BCSS and CAT before and after treatment in the three groups.

Abbreviations: BCSS, Breath, Cough and Sputum Scale; CAT, COPD Assessment Test; HFCWO, high-frequency chest wall oscillation; IPV, intrapulmonary percussive ventilation. 
Table 3 Results of secondary outcomes (hematological, biochemical, and respiratory function parameters)

\begin{tabular}{|c|c|c|c|c|c|c|c|c|c|}
\hline \multirow[t]{3}{*}{ Variable } & \multicolumn{3}{|c|}{ Before treatment } & \multicolumn{3}{|c|}{ After treatment } & \multirow{2}{*}{\multicolumn{3}{|c|}{$\begin{array}{l}\text { Regression analysis } \\
\text { p-value }\end{array}$}} \\
\hline & \multirow{2}{*}{$\begin{array}{l}\text { Control } \\
\text { group }\end{array}$} & \multirow{2}{*}{$\begin{array}{l}\text { IPV } \\
\text { group }\end{array}$} & \multirow{2}{*}{$\begin{array}{l}\text { HFCWO } \\
\text { group }\end{array}$} & \multirow{2}{*}{$\begin{array}{l}\text { Control } \\
\text { group }\end{array}$} & \multirow{2}{*}{$\begin{array}{l}\text { IPV } \\
\text { group }\end{array}$} & \multirow{2}{*}{$\begin{array}{l}\text { HFCWO } \\
\text { group }\end{array}$} & & & \\
\hline & & & & & & & $\begin{array}{l}\text { Control/ } \\
\text { IPV }\end{array}$ & $\begin{array}{l}\text { Control/ } \\
\text { HFCWO }\end{array}$ & $\begin{array}{l}\text { IPVI } \\
\text { HFCWO }\end{array}$ \\
\hline Leukocytes & $8.033 \pm 1.749$ & $7.938 \pm 1.886$ & $7.433 \pm 2.028$ & $9.335 \pm 1.558$ & $7.519 \pm 1.907$ & $7.155 \pm 1.755$ & $<0.001$ & $<0.001$ & 0.7 \\
\hline Neutrophils\% & $65 \pm 9$ & $70 \pm I I$ & $66 \pm 9$ & $71 \pm 9$ & $66 \pm 8$ & $63 \pm 8$ & $<0.001$ & $<0.001$ & 0.4 \\
\hline Lymphocytes\% & $29 \pm 5$ & $21 \pm 7$ & $24 \pm 8$ & $25 \pm 6$ & $23 \pm 6$ & $26 \pm 7$ & $<0.001$ & $<0.001$ & 0.3 \\
\hline CRP & $0.5 \pm 0.5$ & $1.0 \pm 0.7$ & $1.5 \pm 1.7$ & $0.8 \pm 0.5$ & $0.6 \pm 0.4$ & $0.9 \pm 0.9$ & $<0.001$ & $<0.001$ & 0.3 \\
\hline FVC & $2.609 \pm 0.738$ & $1.989 \pm 0.839$ & $2.078 \pm 0.70 \mathrm{I}$ & $2.414 \pm 0.919$ & $2.256 \pm 0.804$ & $2.269 \pm 0.633$ & $<0.001$ & $<0.001$ & 0.7 \\
\hline FVC\% & $65 \pm 10$ & $60 \pm 16$ & $66 \pm 12$ & $59 \pm 12$ & $68 \pm 13$ & $7 I \pm 9$ & $<0.001$ & $<0.001$ & 0.7 \\
\hline $\mathrm{FEV}_{1}$ & $1.155 \pm 0.504$ & $1.013 \pm 0.568$ & $1.236 \pm 0.543$ & $1.045 \pm 0.446$ & $1.195 \pm 0.618$ & $1.349 \pm 0.554$ & $<0.001$ & $<0.001$ & 0.4 \\
\hline $\mathrm{FEV}_{1} \%$ & $35 \pm 9$ & $37 \pm 12$ & $43 \pm 11$ & $31 \pm 9$ & $44.0 \pm 2.1$ & $45.7 \pm 3.6$ & $<0.001$ & $<0.001$ & 0.4 \\
\hline $\mathrm{FEV}_{1} / \mathrm{FVC} \%$ & $45.6 \% \pm 13.4 \%$ & $48.8 \% \pm 13.0 \%$ & $57.5 \% \pm 11.9 \%$ & $43.9 \% \pm 12.2 \%$ & $51.8 \% \pm 11.0 \%$ & $58.8 \% \pm 13.4 \%$ & 0.04 & 0.02 & 0.8 \\
\hline TLC & $5.799 \pm 1.347$ & $7.381 \pm 2.047$ & $5.458 \pm 1.426$ & $5.847 \pm 1.024$ & $5.859 \pm 1.168$ & $5.247 \pm 1.355$ & 0.01 & 0.04 & 0.03 \\
\hline TLC\% & $139 . \pm 2 \mid$ & $|47 . \pm 3|$ & $133 \pm 35$ & $145 \pm 18$ & $137 \pm 23$ & $124 \pm 28$ & 0.01 & 0.04 & 0.04 \\
\hline $\mathrm{RV}$ & $3.73 \mathrm{I} \pm 0.758$ & $4.106 \pm 1.805$ & $3.453 \pm 1.296$ & $3.781 \pm 7 \mid 8$ & $3.708 \pm 1.173$ & $3.299 \pm 1.153$ & 0.02 & 0.02 & 0.04 \\
\hline RV\% & $190 \pm 67$ & $183 \pm 66$ & $146 \pm 37$ & $203 \pm 66$ & $150 \pm 36$ & $136 \pm 29$ & 0.02 & 0.02 & 0.04 \\
\hline RV/TLC\% & $65.1 \% \pm 9.7 \%$ & $67.0 \% \pm 13.5 \%$ & $59.6 \% \pm 9.7 \%$ & $67.9 \% \pm 13.0 \%$ & $63.6 \% \pm 8.1 \%$ & $60.5 \% \pm 9.7 \%$ & 0.01 & 0.01 & 0.05 \\
\hline DLCO\% & $51.0 \% \pm 5.7 \%$ & $60.6 \% \pm 15.0 \%$ & $67.5 \% \pm 12.3 \%$ & $48.5 \% \pm 14.1 \%$ & $67.8 \% \pm 9.1 \%$ & $69.7 \% \pm 5.7 \%$ & $<0.001$ & $<0.001$ & 0.01 \\
\hline MIP (kPa) & $5.8 \pm 2.1$ & $6.2 \pm 2.0$ & $6.8 \pm 2.3$ & $5.3 \pm 1.8$ & $8.1 \pm 2.0$ & $7.5 \pm 2.8$ & $<0.001$ & 0.004 & 0.01 \\
\hline MEP (kPa) & $6.4 \pm 2.4$ & $7.4 \pm 1.9$ & $7.2 \pm 2.1$ & $5.8 \pm 2.0$ & $9.3 \pm 1.4$ & $8.0 \pm 2.4$ & $<0.001$ & $<0.001$ & 0.01 \\
\hline $\mathrm{pO}_{2}$ & $69.1 \pm 10.1$ & $71.8 \pm 7.8$ & $71.8 \pm 10.4$ & $67.9 \pm 9.5$ & $76.3 \pm 6.3$ & $74.8 \pm 9.6$ & $<0.001$ & $<0.001$ & 0.2 \\
\hline $\mathrm{pCO}_{2}$ & $42.0 \pm 5.3$ & $42.5 \pm 4.8$ & $41.7 \pm 3.9$ & $43.1 \pm 6.9$ & $40.4 \pm 3.1$ & $40.3 \pm 3.7$ & 0.003 & 0.004 & 0.8 \\
\hline $\mathrm{HCO}_{3}$ & $24.3 \pm 1.2$ & $23.6 \pm 2.0$ & $24.4 \pm 1.8$ & $24.0 \pm 1.3$ & $23.4 \pm 1.8$ & $23.9 \pm 2.1$ & 0.07 & 0.08 & 0.10 \\
\hline
\end{tabular}

Abbreviations: CRP, C-reactive protein; DLCO, diffusing lung capacity monoxide; FEV , forced expiratory volume in I second; FVC, forced vital capacity; HFCWO, high-frequency chest wall oscillation; IPV, intrapulmonary percussive ventilation; MEP, maximal expiratory pressure; MIP, maximal inspiratory pressure; RV, residual volume; TLC, total lung capacity.

caregiver provide greater control as well as patient satisfaction and are considered important in many areas of medicine (eg, diabetes). Techniques which can be used in a majority of adolescents and adults with pulmonary disease that lead to an increase in adherence with daily therapy have been developed in the recent years. ${ }^{31}$ Thus, methods such as the application of positive expiratory pressure and use of flutter valves or high-frequency chest compression vests have been evaluated with good results in cystic fibrosis patients; these techniques have not been well studied in the COPD patient population. There are a few trials that have studied chest physiotherapy or directed coughing techniques in COPD patients.
These trials have shown some improvements in mucus clearance, but no changes in lung function. ${ }^{2,32,33}$ Several studies have been published regarding the two instruments, both in bronchiectasis and cystic fibrosis patients, ${ }^{8,9,30,34-49}$ or in COPD patients, ${ }^{49-60}$ but only two studies compared IPV and HFCWO. ${ }^{30,61}$ In the previously published studies, IPV reduced the incidence of exacerbations, ${ }^{49,53}$ improved arterial blood gas values, ${ }^{51,53,54,57}$ reduced diaphragmatic workload, ${ }^{50}$ and improved dyspnea, ${ }^{34,51}$ some respiratory functional parameters, ${ }^{34,52,57}$ and sputum volume. ${ }^{30}$ HFCWO showed the following findings: improvement of wet weight sputum or greater sputum expectoration, ${ }^{8,40,43}$ reduction of

Table 4 Changes in sputum cell count

\begin{tabular}{|c|c|c|c|c|c|c|c|c|c|}
\hline \multirow[t]{2}{*}{ Variable } & \multirow{2}{*}{$\begin{array}{l}\text { Control } \\
\text { group }\end{array}$} & \multirow{2}{*}{$\begin{array}{l}\text { IPV } \\
\text { group }\end{array}$} & \multirow{2}{*}{$\begin{array}{l}\text { HFCWO } \\
\text { group }\end{array}$} & \multirow{2}{*}{$\begin{array}{l}\text { Control } \\
\text { group }\end{array}$} & \multirow{2}{*}{$\begin{array}{l}\text { IPV } \\
\text { group }\end{array}$} & \multirow{2}{*}{$\begin{array}{l}\text { HFCWO } \\
\text { group }\end{array}$} & \multicolumn{3}{|l|}{$p$-value } \\
\hline & & & & & & & IPV/control & HFCWO/control & IPV/HFCWO \\
\hline Total cells & $4.52 \pm 1.51$ & $4.83 \pm 135$ & $4.45 \pm I .54$ & $5.26 \pm 1.25$ & 4. $12 \pm 75$ & $3.98 \pm 1.08$ & 0.001 & 0.001 & 0.15 \\
\hline Neutrophils & $7 I \pm 8$ & $72 \pm 11$ & $72 \pm 8$ & $75 \pm 8$ & $61 \pm 9$ & $64 \pm 8$ & 0.001 & 0.001 & 0.05 \\
\hline Lymphocytes & $2.2 \pm 0.5$ & $2.3 \pm 8$ & $2.3 \pm 0.7$ & $1.9 \pm 0.4$ & $2.8 \pm 0.8$ & $2.7 \pm 0.7$ & 0.001 & 0.001 & 0.17 \\
\hline Eosinophils & $2 \pm 1$ & $3 \pm 2$ & $2 \pm 1$ & $2 \pm 1$ & $3 \pm 1$ & $3 \pm 1$ & 0.07 & 0.06 & 0.19 \\
\hline Macrophages & $16 \pm 7$ & $15 \pm 12$ & $16 \pm 10$ & $21 \pm 6$ & $4 \pm 5$ & $16 \pm 5$ & 0.01 & 0.01 & 0.11 \\
\hline
\end{tabular}

Notes: Total cells count 106/g. Neutrophils, lymphocytes, eosynophils, and macrophages are expressed as percentage \pm SD.

Abbreviations: HFCWO, high-frequency chest wall oscillation; IPV, intrapulmonary percussive ventilation. 
Table 5 Ratings and ranking of patient preferences for airway clearance techniques

\begin{tabular}{llll}
\hline Variable & $\begin{array}{l}\text { IPV } \\
\text { group }\end{array}$ & $\begin{array}{l}\text { HFCWO } \\
\text { group }\end{array}$ & p-value \\
\hline Comfort & $3.42 \pm 0.44$ & $3.47 \pm 0.53$ & 0.810 \\
Efficacy & $2.67 \pm 0.94$ & $2.91 \pm 1.08$ & 0.954 \\
Ease of use & $3.04 \pm 0.93$ & $2.64 \pm 0.62$ & 0.072 \\
Convenience & $3.21 \pm 0.33$ & $2.91 \pm 0.16$ & 0.754 \\
\hline
\end{tabular}

Note: Values are expressed as mean \pm SD.

Abbreviations: HFCWO, high-frequency chest wall oscillation; IPV, intrapulmonary percussive ventilation.

dyspnea (Borg score), ${ }^{44,59}$ improvement of healthy scores (CAT and BCSS) and quality of life (St Georges Respiratory Questionnaire), ${ }^{14,60}$ improvement in ventilation distribution and gas mixing, ${ }^{41}$ improvement of respiratory function parameters $\left(\mathrm{FVC}\right.$, and $\left.\mathrm{FEV}_{1}\right),{ }^{8,14,15,41}$ and changes in sputum cell counts. ${ }^{14}$ The study by Varekojis et $\mathrm{al}^{30}$ has compared the therapeutic effectiveness and preference of postural drainage and percussion with IPV and HFCWO. Effectiveness was evaluated by measuring the weight of the wet and dry sputum obtained with each method as well as based on the results of preference obtained by using a Likert-type scale. The wet sputum weight differed significantly and was greater in the IPV group. The second study compared IPV and HFCWO in pediatric tracheostomized patients. IPV was more effective than HFCWO in reducing lower respiratory tract infections, steroid and bronchodilator use, as well as the number of hospitalizations. ${ }^{61}$ Our study has evaluated short-term effects of the two techniques on patients with severe to very severe COPD. We have found a significant improvement in the dyspnea, scores on health status assessment scales, as well as in pulmonary function tests and gas exchange.

Besides, in the group comparison analysis for the same variables between the IPV group and the HFCWO group, a significant improvement in the IPV group in TLC, RV, DLCO, MIP, MEP, BCSS, and CAT was observed. The latter data may suggest that IPV can also act on small bronchial airway obstruction and improve alveolar ventilation. Moreover, the reduction of lung hyperinflation decreases respiratory workload as shown by the reduction of maximal inspiratory and expiratory pressure. Finally, changes in sputum cellularity showed a reduction in the number of inflammatory cells (neutrophils and macrophages) and an increase in the number of lymphocytes as a result of utilization of the two techniques (previously observed for HFCWO) ${ }^{14}$ and suggests a modulation of inflammatory cells (greater for IPV). This is the first study that has investigated sputum cellularity for COPD patients; further studies need to confirm our findings, particularly concerning its impact on exacerbations.

\section{Limitations}

This study has some limitations. It was done in a single center with a relatively modest sample size. We have evaluated only the short-term effects of these techniques; this does not allow us to establish the duration of the effects of the treatment and how many cycles of therapy every patient needs per year.

Moreover, we have not considered the exacerbations; we should have expected a reduction in the number of exacerbations related with the changes in sputum cellularity. Finally, the absence of a sham ventilation therapy group makes our conclusion somewhat less powerful, especially with regard to subjective factors such as dyspnea.

\section{Conclusion}

This study shows that both IPV and HFCWO can improve lung function, muscular strength, dyspnea, and scores on health status assessment scales. IPV demonstrated a greater effectiveness in improving test results linked to small bronchial airways and alveolar ventilation (RV and DLCO) and muscular strength (MIP and MEP) as well as scores on daily life and health status assessment scales (BCSS and CAT) compared with HFCWO. These techniques should be considered as additional therapy in patients with severe to very severe COPD.

\section{Acknowledgments}

The authors thank Mr Giles Wilson, Sales Manager Percussionaire Corporation for his valuable help in reviewing the manuscript and Dr Sergio Lanata, Histopathology Unit, Hospital of Sestri Levante, for his valuable help in data analysis and collection. The abstract of this manuscript was presented at the Poster session of Chest Annual Meeting, Austin, October 25-30, 2014. The publication was financially supported by a grant from Medigas Italia srl.

\section{Disclosure}

The authors have no relevant affiliations or financial involvement with any organization or entity with a financial interest in or financial conflict with the subject matter or materials discussed in the manuscript. The authors report no conflicts of interest in this work.

\section{References}

1. Marcoa R, Rodriguez DM, Dias M, et al. Classification of Chronic Obstructive Pulmonary Disease (COPD) according to the new Global Initiative for Chronic Obstructive Lung Disease (GOLD) 2017: Comparison with GOLD 2011. COPD. Epub 2017 Nov 21.

2. Ramos FL, Krahnke JS, Kim V. Clinical issue of mucus accumulation in COPD. Int J COPD. 2014;9:139-150. 
3. Brightling CE. Chronic obstructive pulmonary disease phenotypes, biomarkers and prognostic factors. Allergy Asthma Proc. 2016;37: 432-438.

4. Woodruff PG, Agusti A, Roche N, Singh D, Martinez FJ. Current concepts in targeting COPD pharmacotherapy: making progress toward personalized management. Lancet. 2015;385:1789-1798.

5. Bott J, Blumenthal S, Buxton M, et al; British Thoracic Society Physiotherapy guideline development Group. Guidelines for the physiotherapy management of the adult, medical, spontaneously breathing patients. Thorax. 2009;64:1-51.

6. Fagevik Olsen M, Westerdahl E. Positive expiratory pressure in patients with chronic obstructive pulmonary disease. A systematic review. Respiration. 2009;77:110-118.

7. Svenningsen S, Paulin GA, Sheikh K, et al. Oscillatory positive expiratory pressure in chronic obstructive pulmonary disease. COPD. 2016;13:66-74.

8. Piquet J, Brochard L, Isabey D, et al. High frequency chest wall oscillation in patients with chronic air-flow obstruction. Am Rev Respir Dis. 1987;136:1355-1359.

9. Nicolini A, Mollar E, Grecchi B, Landucci N. Comparison of intermittent positive pressure breathing and temporary positive expiratory pressure in patients with severe obstructive pulmonary disease. Arch Bronconeumol. 2014;50:18-24.

10. Toussaint M, Guillet MC, Paternott S, Soudon P, Haan J. Intrapulmonary effects of setting parameters in portable intrapulmonary percussive ventilation devices. Respir Care. 2012;57:735-742.

11. Venturelli E, Crisafulli E, DeBiase A, et al. Efficacy of temporary positive expiratory pressure (TPEP) in patients with lung diseases and chronic mucus hypersecretion. The $\mathrm{UNIKO}^{\circledR}$ project: a multicentre randomized controlled trial. Clin Rehabil. 2013;27:336-346.

12. Mascardi V, Grecchi B, Barlascini C, Banfi P, Nicolini A. Effectiveness of temporary positive expiratory pressure (T-PEP) at home and at hospital in patients with severe chronic obstructive pulmonary disease. J Thor Dis. 2016;8:2895-2902.

13. Osadnik CR, McDonald CF, Jones AP, Holland AE. Airway clearance techniques for chronic obstructive pulmonary disease. Cochrane Database Syst Rev. 2012;3:CD008328.

14. Nicolini A, Cardini F, Landucci N, Lanata S, Ferrari-Bravo M, Barlascini C. Effectiveness of treatment with high-frequency chest wall oscillation in patients with bronchiectasis. BMC Pulm Med. 2013;13:21.

15. Lechtzin N, Wolfe LF, Frick KD. The impact of high-frequency chest wall oscillation on healthcare use in patients with neuromuscular diseases. Ann Am Thorac Soc. 2016;13(6):904-909.

16. Cazzola M, Hanania MA, Rudell K, Hackford C, Tamimi N. A review of the most common patient-reported outcomes in COPD-revisiting current knowledge and estimating challenges. Int J COPD. 2015;10: $725-738$.

17. Leidy NK, Rennard S, Schmier J, Jones K, Goldman M. The breathlessness, cough, and sputum scale. The development of empirically based guidelines for interpretation. Chest. 2003;124:2182-2191.

18. Leidy NK, Schmier JK, Jones MK, Lloyd J, Rocchiccioli K. Evaluating symptoms in chronic obstructive pulmonary disease: validation of the Breathlessness, Cough and Sputum Scale. Resp Med. 2003;97: S59-S70.

19. Dodd JW, Hogg L, Nolan J, et al. The COPD assessment test (CAT): response to pulmonary rehabilitation. A multicentre prospective study. Thorax. 2011;66:425-429.

20. Lee BY, Lee S, Lee JS, et al. Validity and reliability of CAT and Dyspnea-12 in bronchiectasis and tuberculosis destroyed lung. Tuber Resp Dis. 2012;72:467-474.

21. Miller MR, Hankinson J, Brusasco V, et al. Standardization of spirometry. Eur Resp J. 2005;26:319-338.

22. Pellegrino R, Viegi G, Brusasco V, et al. Interpretative strategies for lung function tests. Eur Resp J. 2005;26:948-968.

23. Macintyre N, Crapo RO, Viegi G, et al. Standardization of the singlebreath determination of carbon monoxide uptake in the lung. Eur Resp J. 2005;26:720-735.
24. American Thoracic Society/European Respiratory Society. ATS/ERS Statement on respiratory muscle testing. Am J Resp Crit Care Med. 2002; 166:528-621.

25. Evans JA, Whitelaw WA. The assessment of maximal respiratory mouth pressure in adults. Respir Care. 2009;54:1348-1359.

26. Vestbo J, Hurd SS, Agusti AG, et al. Global strategies for diagnosis and prediction of chronic pulmonary disease. Gold executive summary. Am J Resp Crit Care Med. 2013;187:347-365.

27. Moritz P, Steidle LJ, Felisbino MB, Kleveston T, Pizzichini MM, Pizzichini E. Determination of the inflammatory component of airway diseases by induced sputum cell counts: use in clinical practice. J Bras Pneumol. 2008;34:913-921.

28. Staticescu S, Chereches-Panta P, Ichimi G, Valeanu M, Nanulescu MV. The value of induced sputum in the diagnosis and management of children with bronchial asthma. Clujul Med. 2014;87:171-176.

29. Gupta V, Singh D. Critical assessment of the value of sputum neutrophils. COPD. 2013;10:107-114.

30. Varekojis SM, Douce H, Flucke RL, et al. A comparison of the therapeutic effectiveness of and preference for postural drainage and percussion, intrapulmonary percussive ventilation, and high-frequency chest wall compression in hospitalized cystic fibrosis patients. Respir Care. 2003;48:24-28.

31. Pryor JA. Physiotherapy for airway clearance in adults. Eur Resp J. 1999;14:1418-1424.

32. Warnock L, Gates A, van der Schans CP. Chest physiotherapy compared to no chest physiotherapy for cystic fibrosis. Cochrane Database Syst Rev. 2013;9:CD001401.

33. van der Schans CP. Conventional chest physical therapy for obstructive lung disease. Respir Care. 2007;52:1198-1206.

34. Paneroni M, Clini E, Simonelli C, Bianchi L, Degli Antoni F, Vitacca M. Safety and efficacy of short-term intrapulmonary percussive ventilation in patients with bronchiectasis. Respir Care. 2011;56:984-988.

35. Dmello D, Navak RP, Matuschak GM. High-frequency percussive ventilation for airway clearance in cystic fibrosis: a brief report. Lung. 2010;3:511-513.

36. Newhouse PA, White F. The intrapulmonary percussive ventilation and flutter device compared to chest physiotherapy in patients with cystic fibrosis. Clin Pediatr. 1998;37:427-432.

37. Natale JE, Pfeifle J, Hommick DN. Comparison of intrapulmonary percussive ventilation and chest physiotherapy: a pilot study in patients with cystic fibrosis. Chest. 1994;105:1789-1793.

38. Homnick DN, White F, de Castro C. Comparison of effects of an intrapulmonary percussive ventilator to standard aerosol and chest physiotherapy in treatment of cystic fibrosis. Pediatr Pulmonol. 1995; 20:50-55.

39. Van Ginderdeuren F, Verbanck S, Van Cauwelaert K, et al. Chest physiotherapy in cystic fibrosis: short-term effects of autogenic drainage preceded by wet inhalation of saline versus autogenic drainage preceded by intrapulmonary percussive ventilation with saline. Respiration. 2008;100:1526-1533.

40. Arens R, Gozal D, Omlin KJ, et al. Comparison of high frequency chest compression and conventional chest physiotherapy in hospitalized patients with cystic fibrosis. Am J Resp Crit Care Med. 1994;150:1154-1157.

41. Darbee JC, Kanga JF, Ohtake PJ. Physiologic evidence for highfrequency chest wall oscillation and positive expiratory pressure breathing in hospitalized subjects with cystic fibrosis. Phys Ther. 2005;85: 1278-1289.

42. Phililips GE, Pike SE, Jaffe' A, Bush A. Comparison of active cycle of breathing and high-frequency oscillation jacket in children with cystic fibrosis. Pediatr Pulmonol. 2004;37:71-75.

43. Kempainen RR, Milla C, Dunitz J, et al. Comparison of settings used for high-frequency chest-wall compression in cystic fibrosis. Respir Care. 2010;55(6):695-701.

44. Fainardi V, Longo F, Faverzani S, Tripodi MC, Chetta A, Pisi G. Short-term effects of high-frequency chest compression and positive expiratory pressure in patients with cystic fibrosis. J Clin Med Res. 2011;3(6):279-284. 
45. Oermann CM, Stroker MM, Giles D, Sontag M, Accurso FJ, Castile RG. Comparison of high-frequency chest wall oscillation and oscillating positive expiratory pressure in the home management of cystic fibrosis: a pilot study. Pediatr Pulmonol. 2001;32:372-377.

46. Kempainen RR, Williams CB, Hazelwood A, Rubin BK, Milla CE. Comparison of high-frequency chest wall oscillation with differing waveform for airway clearance in cystic fibrosis. Chest. 2007;132: 1227-1232.

47. Mcllwaine MP, Alarie N, Davidson GF, et al. Long-term multicentre randomised controlled study of high frequency chest wall oscillation versus positive expiratory pressure mask in cystic fibrosis. Thorax. 2013;68:746-751.

48. Osman LP, Roughton M, Hodson ME, Pryor JA. Short-term comparative of high frequency chest wall oscillation and European airway clearance techniques in patients with cystic fibrosis. Thorax. 2010;65: 196-200.

49. Degreef JM, Crepin JL, Deroubalx C, et al. Reduction du nombre de superinfections bronchiques par la ventilation a percussion intrapulmonaire, chez de patients atteints de bronchopneumopaties chroniques obstructives (BPCO) ou de bronchiectasies (DDB). Rev Mal Resp. 2003;1S89:129.

50. Nava S, Barbarito N, Piaggi G, De Mattia E, Cirio S. Physiological response to intrapulmonary percussive ventilation in stable COPD patients. Respir Med. 2006;100:1526-1533.

51. Testa A, Galeri S, Villafane JH, Corbellini C, Pillastrini P, Negrini S Efficacy of short-term intrapulmonary percussive ventilation in patients with chronic obstructive pulmonary disease. Disabil Rehabil. 2015;37: 899-903.

52. Vargas F, Boyer A, Bui HN, Guenard H, Gruson D, Hilbert G. Effect of intrapulmonary percussive ventilation on expiratory flow limitation in chronic obstructive pulmonary disease patients. J Crit Care. 2009; $24: 212-219$
53. Vargas F, Bui NH, Boyer A, et al. Intrapulmonary percussive ventilation in acute exacerbation of COPD patients with mild respiratory acidosis: a randomized controlled trial. Crit Care. 2005;9:R382-R389.

54. Antonaglia V, Lucangelo U, Zin WA, et al. Intrapulmonary percussive ventilation improves the outcome of patients with acute exacerbations of COPD using helmet. Crit Care Med. 2006;34:2940-2945.

55. Dimassi S, Vargas F, Lyazidi A, et al. Intrapulmonary percussive ventilation superimposed on spontaneous breathing: a physiological study in patients at risk for extubation failure. Intensive Care Med. 2011; $37: 1269-1276$

56. Ides K, Vos W, de Backer L, et al. Acute effects of intrapulmonary percussive ventilation in COPD patients assessed by using conventional outcome parameters and a novel computational fluid dynamics technique. Int J COPD. 2012;7:667-671.

57. Clini EM, Antoni FD, Vitacca M, et al. Intrapulmonary percussive ventilation in tracheostomized patients: a randomized controlled trial Intensive Care Med. 2006;32:1994-2001.

58. Braverman J, Nozzarella MJ. High-frequency chest compression: advanced therapy for obstructive lung disease. Respir Ther. 2007;2 48-51.

59. Mahajan AK, Diette GB, Hatipoglu U, et al. High frequency chest wall oscillation for asthma and chronic obstructive pulmonary disease exacerbations: a randomized sham-controlled clinical trial. Respir Res. 2011;12:20

60. Chakravorty I, Chahal K, Austin G. A pilot study of the impact of high-frequency chest wall oscillation in chronic obstructive pulmonary disease patients with mucus hypersecretion. Int J COPD. 2011;6: 693-699.

61. Bidiwala A, Volpe L, Halaby C, Fazzari M, Valsamis C, Pirzada M. A comparison of high frequency chest wall oscillation and intrapulmonary percussive ventilation for airway clearance in pediatric patients with tracheostomy. Postgrad Med. 2017;129:276-282.
International Journal of COPD

\section{Publish your work in this journal}

The International Journal of COPD is an international, peer-reviewed journal of therapeutics and pharmacology focusing on concise rapid reporting of clinical studies and reviews in COPD. Special focus is given to the pathophysiological processes underlying the disease, intervention programs, patient focused education, and self management protocols.

\section{Dovepress}

This journal is indexed on PubMed Central, MedLine and CAS. The manuscript management system is completely online and includes a very quick and fair peer-review system, which is all easy to use. Visit http://www.dovepress.com/testimonials.php to read real quotes from published authors. 